\title{
Strategic transformation of regionalization for the agricultural comprehensive development: The example of Ningxia Hui Autonomous Region in China
}

\author{
SHI Wenjiao ${ }^{1,2,3}$, HU Yunfeng ${ }^{1}$, SHI Xiaoli, ${ }^{4,5}$, WANG Zong ${ }^{1,6}$, YAN Huimin ${ }^{1,3}$, \\ XU Ziwei ${ }^{2}$, REN Bo ${ }^{1}$, KUANG Wenhui $^{1}$, XU Xinliang ${ }^{1}$, CHENG Weiming ${ }^{1}$, \\ CHEN Yan ${ }^{7}$, WU Dongbo
}

1. Key Laboratory of Land Surface Pattern and Simulation, Institute of Geographic Sciences and Natural Resources Research, CAS, Beijing 100101, China;

2. State Key Laboratory of Remote Sensing Science, School of geography, Beijing Normal University, Beijing 100875, China;

3. College of Resources and Environment, University of Chinese Academy of Sciences, Beijing 100049, China;

4. College of Resources and Environment Sciences, Hebei Normal University, Shijiazhuang 050024, China;

5. Key Laboratory of Environmental Evolvement and Ecological Construction of Hebei Province, Shijiazhuang 050024, China;

6. School of Earth Sciences and Resources, China University of Geosciences, Beijing 100083, China;

7. Ningxia Agricultural Comprehensive Development Office, Yinchuan 750011, China

\begin{abstract}
Strategic transformation of regionalization for agricultural comprehensive development (ACD) was presented by the Ministry of Finance of the People's Republic of China (MOF) in 2014. The regionalization is the premise and basis of the sustainable development and improved competitiveness for agriculture. Based on the environmental resources related to agriculture, such as cropland, climate, water resources, terrain, geomorphology, patterns of the ACD projects, distribution of ecological planning, etc., we devised 13 indices using the geographic comprehensive regionalization method. The indices took into account a combination of dynamic and static, qualitative and quantitative, as well as agricultural and ecological factors. The strategic transformation of regionalization for the ACD in Ningxia Hui Autonomous Region of China was performed; seven types were included: prioritized regions, prioritized and restricted regions, protected regions, protected and restricted regions, restricted and prioritized regions, restricted and protected regions, and restricted regions. A further 24 subtypes were used based on locations and ecological zones. The regionalization results showed that prioritized regions were mainly in northern Ningxia, the most suitable area for agriculture. The protected and restricted regions were in central and southern Ningxia. In the central part, drought was the limiting factor for agriculture, and water conservation projects there should be supported. The ecological environment is fragile in southern Ningxia, so there is a need for ecologically sound agriculture to be developed in this region. Such regionaliza-
\end{abstract}

Received: $2015-12-13$ Accepted: 2016-01-10

Foundation: National Natural Science Foundation of China, No.41371002, No.41301355, No.41401113; The Open Fund of State Key Laboratory of Remote Sensing Scienc, No.OFSLRSS201622

Author: Shi Wenjiao, PhD and Associate Professor, specializing in global change and agriculture, spatial analysis and geostatistics. E-mail: shiwj@1reis.ac.cn 
tion could achieve two goals, namely agricultural conservation and eco-environmental protection. It was performed following the requirement for scientific regionalization to include three types of regions (prioritized regions, protected regions, and restricted regions), and was applied at the township scale in a provincial or autonomous region for the first time. The results provide both guidance for the strategic transformation of the ACD in Ningxia, and a reference for similar work in other provinces.

Keywords: agricultural comprehensive development (ACD); regionalization; sustainable development; indices; Ningxia

\section{Introduction}

Agricultural comprehensive development (ACD) has contributed greatly to the strengthening of agricultural infrastructure, thus guaranteeing national food security and increasing farmers' income in China. However, the previous ACD projects have covered almost all the agricultural counties in China, and some phenomena have not been well adapted to the local resources and environment alongside development, such as insufficient attention to the carrying capacity of water resources, soil conditions, and comprehensive treatment of the ecological environment. During the period of strategic transformation, ACD is also facing new challenges with the development of the economy and society in China. On the one hand, the resource and environmental problems have become increasingly prominent; on the other hand, the costs of agricultural production are increasing, and price subsidies provided by the government are approaching an upper limit. These new challenges demand that future agricultural development should be changed from extensive management to sustainable intensive development, and also from pursuing production volumes and depending on resource consumption to focusing on both the quantity and quality of agricultural productivity and improving competitiveness and agricultural technological innovation. Therefore, a mandate for sustainable development and improved competitiveness in the ACD was presented by the Ministry of Finance of the People's Republic of China (MOF) in 2014. In order to achieve the goals of high yield, high efficiency, and sustainable use of resources, it was suggested that prioritized, protected, and restricted regions should be denoted. This aimed to achieve modern agricultural development characterized by highly efficient output, product safety, and the efficient use of resources in an environmentally friendly manner.

Previous research into agricultural regionalization in China mainly included the single or integrated regionalization of resources (such as climate, soil, terrain, water resources, and vegetation), agricultural department regionalization (such as agriculture, forestry, husbandry, fishery, and crop division), the reform of agricultural technology divisions (irrigation, agricultural mechanization, fertilizers, soil quality improvement, etc.), and comprehensive regionalization of agriculture (Deng, 1982). There have been three versions of large-scale agriculture regionalization in China since 1949 (Tao and Chen, 2014). In 1953, the Ministry of Agriculture demanded regionalization in each province to accelerate the development of agricultural productivity through solving the problems of regional development and the rational allocation of agriculture (The Agricultural Regionalization Research Team of Geographical Society of China, 1965; Zhou, 1957). The Preliminary Opinions of National Agricultural Regionalization was published in 1955 and divided the Chinese agricultural regions into six types and sixteen subtypes (Deng, 1960). The National Regionalization of Agricul- 
tural Status (Draft) published in 1962 classified the whole China into four primary zones, 12 secondary zones, 51 third level zones, and 129 fourth level zones (Deng, 1963). The Agricultural Regionalization for Agricultural Modernization was proposed during the 1970s-1980s (Zhou, 1979; Zhou, 1981). The Comprehensive Agricultural Regionalization in China published in the 1980 s, provided a strong impetus to carry out agricultural regionalization in different provinces, cities, and autonomous regions (Zhou et al., 1981). With the initial completion of agricultural regionalization, regional agricultural systems have been researched in detail (Deng, 1984). The theoretical system of agricultural regionalization was gradually formed in the 1990s (Zhou, 1993). After 2000, more and more research regarding suitable regionalization based on different natural conditions has been evaluated using quantitative models (Chen et al., 2012; Liu et al., 2013; Wang et al., 2013; Liu et al., 2010; Miao et al., 2015; Lv et al., 2007). In addition, the consequences of regionalization in China, e.g. comprehensive physiographical regionalization (Liu et al., 2005; Lin, 1954; Huang, 1959; Hou, 1988; Ren and Yang, 1961; Zhao, 1983; Zheng, 2008; Wu and Liu, 2005), the major function-oriented zoning (Fan, 2015; Gu et al., 2007; Wang et al., 2010; Fan and Li, 2009), soil and water conservation regionalization (Zhao et al., 2013), climate regionalization (Zheng et al., 2010), the zoning of China's integrated land consolidation (Feng et al., 2006), ecosystem productivity regionalization (Xu et al., 2001), ecological regionalization (Xie et al., 2012), and geomorphological regionalization (Li et al., 2013) have all played important roles in guiding agricultural production since the 1950s.

Ningxia Hui Autonomous Region, located between $104^{\circ} 17^{\prime}-107^{\circ} 40^{\prime} \mathrm{E}$ and $35^{\circ} 14^{\prime}-$ $39^{\circ} 23^{\prime} \mathrm{N}$, is on the upper-middle reaches of the Yellow River in northwestern China. The total area is 51.9 thousand $\mathrm{km}^{2}$. Ningxia is divided into three regions, including an irrigated area in the north, an arid area in the center, and a loess hilly area in the south. The study area has a typical continental climate with an annual average temperature of $5-9^{\circ} \mathrm{C}$ from south to north and an annual precipitation of $183-677 \mathrm{~mm}$ from north to south. It is located in the transitional zone of the Inner Mongolia Plateau and the Loess Plateau, and the altitude is 713-3545 m from north to south. The level of economic development of the northern Yellow River irrigation area is relatively high, while the economy in the center and the south is relatively backward. In summary, adequate sunshine, a large diurnal temperature range, and a clean environment are ideal for the development of high-quality agricultural production, such as grains, wolfberry (goji berry), and halal beef and mutton. In the north of Ningxia, the availability of cultivated land, proximity to the Yellow River irrigation area (irrigated area in the north), and adequate sunshine and heat are beneficial to agriculture. Elsewhere, in contrast, there is an obvious shortage of water resources (arid area in the center) and restrictions caused by the fragile ecology (loess hilly area in the south). The ACD of Ningxia is now in a period of both transitional adjustment and opportunity, so it is necessary to understand environmental factors such as water, soil, air and ecology, to propose suggestions for spatial distribution and development measures for the ACD projects. The geographical comprehensive regionalization method was used to establish the strategic transformation of regionalization for the $\mathrm{ACD}$, including prioritized regions, protected regions, and restricted regions. Therefore, we took the Ningxia Hui Autonomous Region of China as an example to propose a strategic transformation of regionalization of the three regions. The strategic transformation of regionalization for the ACD can be helpful in the top-down scientific de- 
sign of projects for national or local agricultural development, so that development policies can be made according to local conditions. Furthermore, it will help promote integration and targeted investment, so that the combination of development policies and regional functions can achieve sustainable agricultural development and promote competitiveness. Three aspects of the strategic transformation of regionalization for the ACD in Ningxia are significant. First, it can promote construction of the "Silk Road Economic Belt" and the "Bridge-head" of westward opening. Second, it can facilitate the implementation of the national policy of strategic transformation of regionalization in Ningxia. Third, it can serve the development of modern agriculture, and can provide reasonable ACD planning and advices in spatial pattern.

\section{Regionalization framework}

The framework of strategic transformation of regionalization for Ningxia ACD was established to accomplish two core targets: mandatory sustainable development, and improved competitiveness (Figure 1). Various plans from national government, as well as from the Western and Ningxia Departments of Development and Reform Commission, Agriculture, Land, Water, Forestry, Environmental Protection, Science and Technology, Food, Poverty Alleviation, and so on, were combined with the strategy for transformation of regionalization. The evaluation indices were devised through the spatial analysis of multi- source features using GIS tools, including climate (precipitation), water resources (recharge modulus of groundwater), terrain (slope), geomorphology (plain, hill, and mountain), and ecological functional area planning (agricultural function region), and other parameters. In this framework, we have divided the whole region into prioritized regions, protected regions, and restricted regions at a township scale. First, the prioritized regions are the areas of

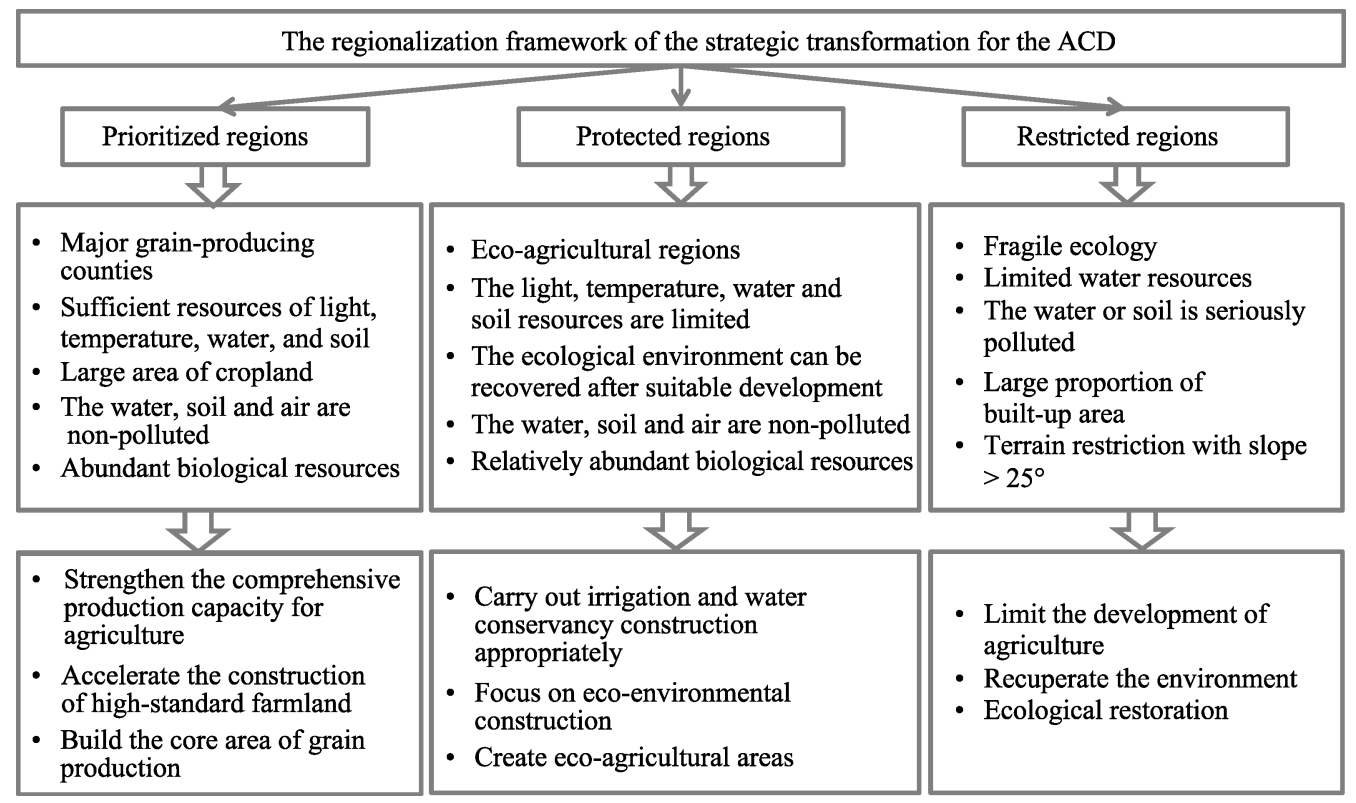

Figure 1 The regionalization framework of strategic transformation for Ningxia Agricultural Comprehensive Development (ACD) 
abundant natural and environment resources where can be managed according to the principle of sustainable use. These regions are core areas of grain production, and high standard farmland should be developed to ensure the output. In addition, the ecological environment should be protected in these regions. Second, the protected regions have the potential to achieve ecological balance after development; the resilience of resources is limited in these regions. These regions should be appropriately developed as eco-agricultural areas with irrigation and water conservation, and focus should be placed on the construction of an ecological agricultural area in Ningxia. Third, the restricted regions have a poor resilience of resources and environment in these fragile ecological areas. Large-scale land reclamation should be forbidden in these regions in order to restore the ecological environment.

\section{Regionalization process and index system}

\subsection{Regionalization process}

The technical route for the strategic transformation of regionalization for Ningxia is shown in Figure 2. (I) The index system, including temperature, water, soil, and other natural resources in Ningxia, was established; (II) The suitability levels of these indices for

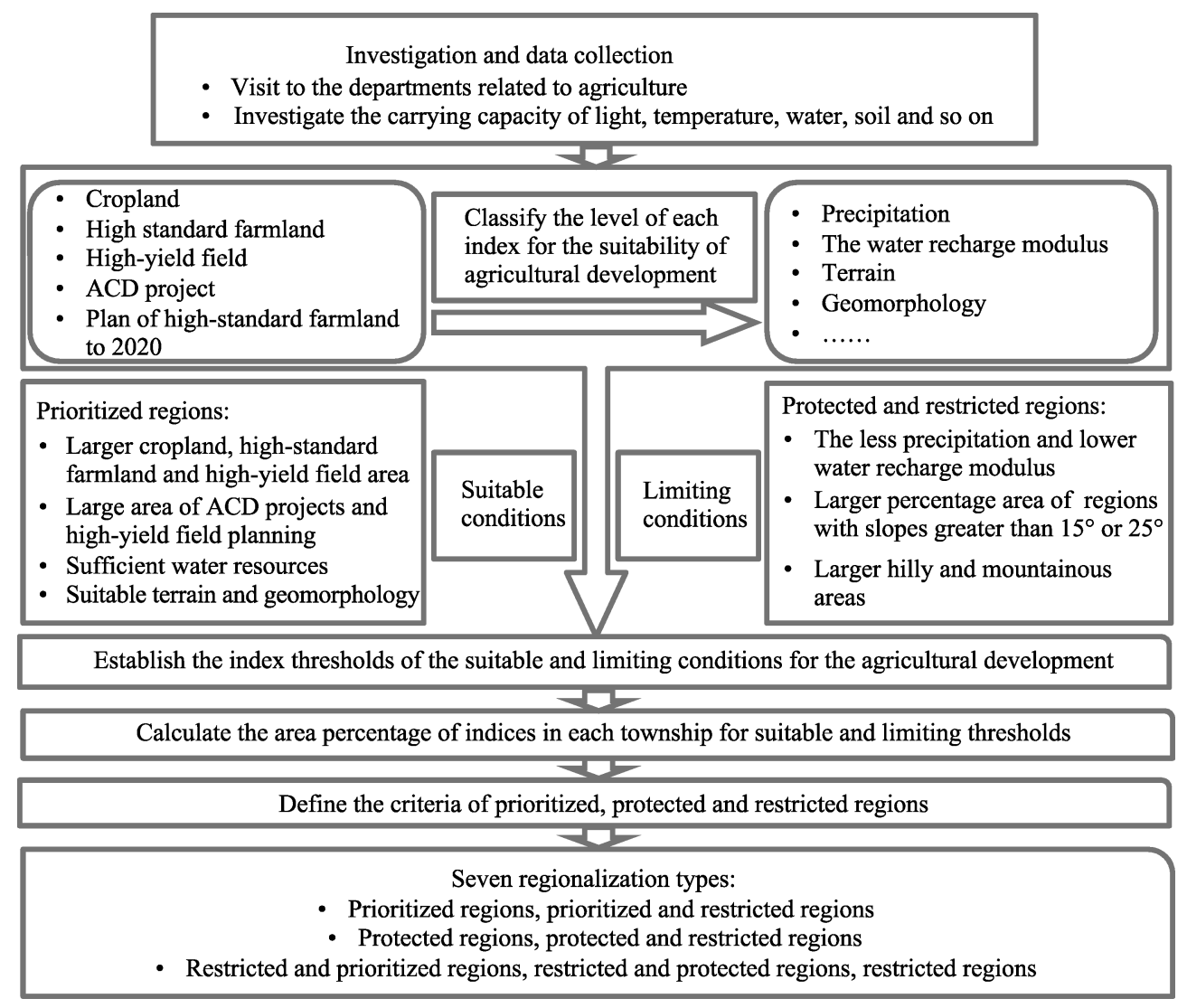

Figure 2 The technical route for strategic transformation of regionalization for Ningxia Agricultural Comprehensive Development 
agricultural production were evaluated according to the spatial distribution of cropland, high standard farmland, high-yield fields, ACD projected areas, the plan of high-standard farmland in Ningxia for 2020, etc.; (III) The necessary conditions for prioritized, protected, and restricted regions were determined by the evaluation of each index; (IV) According to the suitability levels of different indices from III, the limiting indices and the levels for the agricultural development in Ningxia were identified; (V) Index thresholds for the suitable and limiting conditions in the prioritized regions, protected regions, and restricted regions were established; (VI) A percentage area of each index of the suitable and limiting thresholds were calculated at a township scale; (VII) The criteria of the three regions were defined according to the spatial distribution of each index threshold in each township, and the regionalization types were classified according to the criteria.

In general, the regionalization types are transitional, gradual, or mixed due to the complexity and non-uniformity in each township. If the characters of two types are typical in one township, then the two types are named as a mixed type. There are seven types in our regionalization: prioritized regions, prioritized and restricted regions, protected regions, protected and restricted regions, restricted and prioritized regions, restricted and protected regions, as well as restricted regions.

\subsection{Index system of regionalization}

The indices related to the sustainable and limiting conditions for the ACD were selected as an important basis for dividing regionalization types and subtypes. The indices were considered in combinations of dynamic and static, qualitative and quantitative, and agricultural and ecological factors. There were seven types of indices: cropland, water resources, climate, terrain, landform, ACD projects, and ecological planning. For cropland, the percentage areas of cropland, basic farmland, and high-yielding fields in each township were selected to represent the proportion of cropland or high-quality cropland. For water resources, the percentage areas with a recharge modulus of greater than $200,000 \mathrm{~m}^{3} /\left(\mathrm{a} \cdot \mathrm{km}^{2}\right)$ or lower than 10,000 $\mathrm{m}^{3} /\left(\mathrm{a} \cdot \mathrm{km}^{2}\right)$ were used to represent the volume of water resources used for agricultural irrigation. For climate, we chose the percentage area with precipitation lower than $200 \mathrm{~mm}$ to represent the amount of precipitation. For terrain, we selected percentage areas above $15^{\circ}$ or $25^{\circ}$ slope to represent the limiting factor of the terrain. For geomorphology, the percentage areas of mountains, hills, and plains were selected in order to analyze the suitability of the ACD. For distribution of the ACD projects, the percentage areas of high-standard farmland projects and the planning projects to 2020 represent developed levels in the past and future. For ecological planning, the percentage area devoted to agriculture-related functions was selected as being representative of agricultural importance. The specific data sources for each index are shown in Table 1.

\section{Results and analysis}

\subsection{Naming rules}

There are three basic regionalization types (prioritized regions, protected regions, and restricted regions) and four transitional types (prioritized and restricted regions, protected 
Table 1 The index system of the strategic transformation of regionalization for Ningxia Agricultural Comprehensive Development

\begin{tabular}{|c|c|c|c|}
\hline Index types & Indices & Data sources & Thresholds \\
\hline \multirow{3}{*}{ Cropland } & $\begin{array}{l}\text { The percentage area } \\
\text { of cropland in town- } \\
\text { ships }\end{array}$ & $\begin{array}{l}\text { Land-use map of Ningxia } \\
\text { (The Second Land Survey of } \\
\text { Ningxia Hui Autonomous } \\
\text { Region Atlas Compilation } \\
\text { Committee, 2012) }\end{array}$ & $\begin{array}{l}\text { Prioritized regions: }>50 \% \text { with suffi- } \\
\text { cient water resources } \\
\text { Protected or mixed regions: } 10 \%-50 \% \\
\text { Restricted regions: }<10 \%\end{array}$ \\
\hline & $\begin{array}{l}\text { The percentage area } \\
\text { of basic farmland in } \\
\text { townships }\end{array}$ & $\begin{array}{l}\text { The distribution map of basic } \\
\text { farmland in Ningxia (The } \\
\text { Second Land Survey of } \\
\text { Ningxia Hui Autonomous } \\
\text { Region Atlas Compilation } \\
\text { Committee, 2012) }\end{array}$ & $\begin{array}{l}\text { Prioritized regions: }>50 \% \\
\text { Protected or mixed regions: } 5 \%-50 \% \\
\text { Restricted regions: }<5 \%\end{array}$ \\
\hline & $\begin{array}{l}\text { The percentage area } \\
\text { of high-yield farm- } \\
\text { land in townships }\end{array}$ & $\begin{array}{l}\text { Simulation results from light } \\
\text { use efficiency model (Ji et al., } \\
2015)\end{array}$ & $\begin{array}{l}\text { Prioritized regions: }>50 \% \\
\text { Protected or mixed regions: } 5 \%-50 \% \\
\text { Restricted regions: }<5 \%\end{array}$ \\
\hline \multirow[b]{2}{*}{ Water resources } & $\begin{array}{l}\text { The percentage area } \\
\text { of water recharge } \\
\text { modulus higher than } \\
200,000 \mathrm{~m}^{3} / \mathrm{a} \cdot \mathrm{km}^{2} \text { in } \\
\text { townships }\end{array}$ & $\begin{array}{l}\text { The distribution map of } \\
\text { groundwater resources in } \\
\text { Ningxia (Government of the } \\
\text { Ningxia Hui Autonomous } \\
\text { Region, 2013) }\end{array}$ & $\begin{array}{l}\text { A percentage area of more than } 50 \% \\
\text { with a water recharge modulus greater } \\
\text { than } 200,000 \mathrm{~m}^{3} / \mathrm{a} \cdot \mathrm{km}^{2} \text {, indicating that } \\
\text { water is abundant in this township. }\end{array}$ \\
\hline & $\begin{array}{l}\text { The percentage area } \\
\text { of water recharge } \\
\text { modulus less than } \\
10,000 \mathrm{~m}^{3} / \mathrm{a} \cdot \mathrm{km}^{2} \text { in } \\
\text { townships }\end{array}$ & $\begin{array}{l}\text { The distribution map of } \\
\text { groundwater resources in } \\
\text { Ningxia (Government of the } \\
\text { Ningxia Hui Autonomous } \\
\text { Region, 2013) }\end{array}$ & $\begin{array}{l}\text { A percentage area of more than } 50 \% \text { for } \\
\text { which the precipitation lower than } 200 \\
\text { mm and a relatively large percentage } \\
\text { area for which the water recharge } \\
\text { modulus is less than } 10,000 \mathrm{~m}^{3} / \mathrm{a} \cdot \mathrm{km}^{2} \\
\text { in the township, which together indi- } \\
\text { cate that water is relatively scarce in } \\
\text { the township. }\end{array}$ \\
\hline Climate & $\begin{array}{l}\text { The percentage area } \\
\text { of precipitation less } \\
\text { than } 200 \mathrm{~mm}\end{array}$ & $\begin{array}{l}\text { The interpolation of precipi- } \\
\text { tation results from meteoro- } \\
\text { logical station data. }\end{array}$ & $\begin{array}{l}\text { A percentage area of more than } 50 \% \text { for } \\
\text { which the precipitation lower than } 200 \\
\text { mm and a relatively large percentage } \\
\text { area for which the water recharge } \\
\text { modulus is less than } 10,000 \mathrm{~m}^{3} / \mathrm{a} \cdot \mathrm{km}^{2} \\
\text { in the township, which together indi- } \\
\text { cate that water is relatively scarce in } \\
\text { the township. }\end{array}$ \\
\hline \multirow[b]{2}{*}{ Terrain } & $\begin{array}{l}\text { The percentage area } \\
\text { of slope above } 15^{\circ}\end{array}$ & $\begin{array}{l}\text { The calculated results of } \\
\text { slope from } 30 \text { m-resolution } \\
\text { DEM data }\end{array}$ & $\begin{array}{l}\text { Protected or restricted regions: the } \\
\text { percentage area of slope }>15^{\circ} \text { is more } \\
\text { than } 50 \% \text {. }\end{array}$ \\
\hline & $\begin{array}{l}\text { The percentage area } \\
\text { of slope above } 25^{\circ}\end{array}$ & $\begin{array}{l}\text { The calculated results of } \\
\text { slope from } 30 \text { m-resolution } \\
\text { DEM data }\end{array}$ & $\begin{array}{l}\text { Restricted regions: the percentage area } \\
\text { of slope }>25^{\circ} \text { is more than } 50 \% \text {. } \\
\text { Protected or restricted regions: the } \\
\text { percentage area of slope }>25^{\circ} \text { is be- } \\
\text { tween } 20 \% \text { and } 50 \% \text {. }\end{array}$ \\
\hline \multirow{2}{*}{ Geomorphology } & $\begin{array}{l}\text { The percentage area } \\
\text { of mountains and } \\
\text { hills }\end{array}$ & $\begin{array}{l}\text { Digital Land Geomorphology } \\
\text { of } 1: 1000000 \text { in China (Zhou } \\
\text { et al., 2009) }\end{array}$ & $\begin{array}{l}\text { An index }>50 \% \text { indicates that the } \\
\text { township is limited by geomorphology. }\end{array}$ \\
\hline & $\begin{array}{l}\text { The percentage area } \\
\text { of plains }\end{array}$ & $\begin{array}{l}\text { Digital Land Geomorphology } \\
\text { of } 1: 1000000 \text { in China (Zhou } \\
\text { et al., 2009) }\end{array}$ & $\begin{array}{l}\text { An index }>50 \% \text { indicates that the } \\
\text { township is unlimited by geomorphol- } \\
\text { ogy. }\end{array}$ \\
\hline \multirow[b]{2}{*}{$\begin{array}{l}\text { The distribu- } \\
\text { tions of ACD } \\
\text { projects }\end{array}$} & $\begin{array}{l}\text { The percentage area } \\
\text { of ACD projects in } \\
\text { townships }\end{array}$ & $\begin{array}{l}\text { The distribution of ACD } \\
\text { projects from } 2004 \text { to } 2013\end{array}$ & $\begin{array}{l}\text { Prioritized regions: the percentage area } \\
\text { of ACD projects is }>50 \% \text { in townships. } \\
\text { Protected or restricted regions: the } \\
\text { percentage area is }<10 \% \text { in township. }\end{array}$ \\
\hline & $\begin{array}{l}\text { The percentage area } \\
\text { of high-standard } \\
\text { farmland planning in } \\
\text { townships }\end{array}$ & $\begin{array}{l}\text { The spatial distributions of } \\
\text { high-standard farmland plan- } \\
\text { ning from } 2014 \text { to } 2020\end{array}$ & $\begin{array}{l}\text { Prioritized regions: the percentage area } \\
\text { of high-standard farmland planning is } \\
>50 \% \text { in townships. } \\
\text { Prioritized or protected regions: the } \\
\text { percentage area of high-standard farm- } \\
\text { land planning is between } 20 \% \text { and } 50 \% \\
\text { in township. }\end{array}$ \\
\hline $\begin{array}{l}\text { Ecological } \\
\text { planning }\end{array}$ & $\begin{array}{l}\text { The percentage area } \\
\text { of the agricultural } \\
\text { related functions in } \\
\text { Agricultural Eco- } \\
\text { logical Planning }\end{array}$ & $\begin{array}{l}\text { The 12th Five-year Plan for } \\
\text { ecological construction in } \\
\text { Ningxia }\end{array}$ & $\begin{array}{l}\text { Prioritized or protected regions: the } \\
\text { percentage area is }>50 \% \text {. }\end{array}$ \\
\hline
\end{tabular}


and restricted regions, restricted and prioritized regions, as well as restricted and protected regions). Roman numerals are used in the type names, such as "I prioritized regions", "II prioritized and restricted regions", and so on.

The names of the subtypes reflect not only the seven major types of regionalization but also the ecological location of the division unit, such as "IV1 the protected regions with water-saving irrigation pumped from the Yellow River and the restricted regions with soil erosion", or "VII5 restricted regions returning cropland to grassland", and so on. In addition, if the region had an obvious regional feature, we named the region according to the sequential geographic location, ecological zone, and development type; for example, "I1 the prioritized regions with paddydryland rotations in the south of Yinchuan", "V1 the restricted regions with forest and grass on Helan Mountain, and the prioritized regions with irrigated dryland in the north of Yinchuan", and so on.

\subsection{Regionalization types}

The distribution of the seven regionalization types, including prioritized regions, prioritized and restricted regions, protected regions, protected and restricted regions, restricted and prioritized regions, restricted and protected regions, and restricted regions, is shown in Figure 3 and Table 2. There are $44,3,23,5,17,83$, and 20 townships in the seven types, respectively.

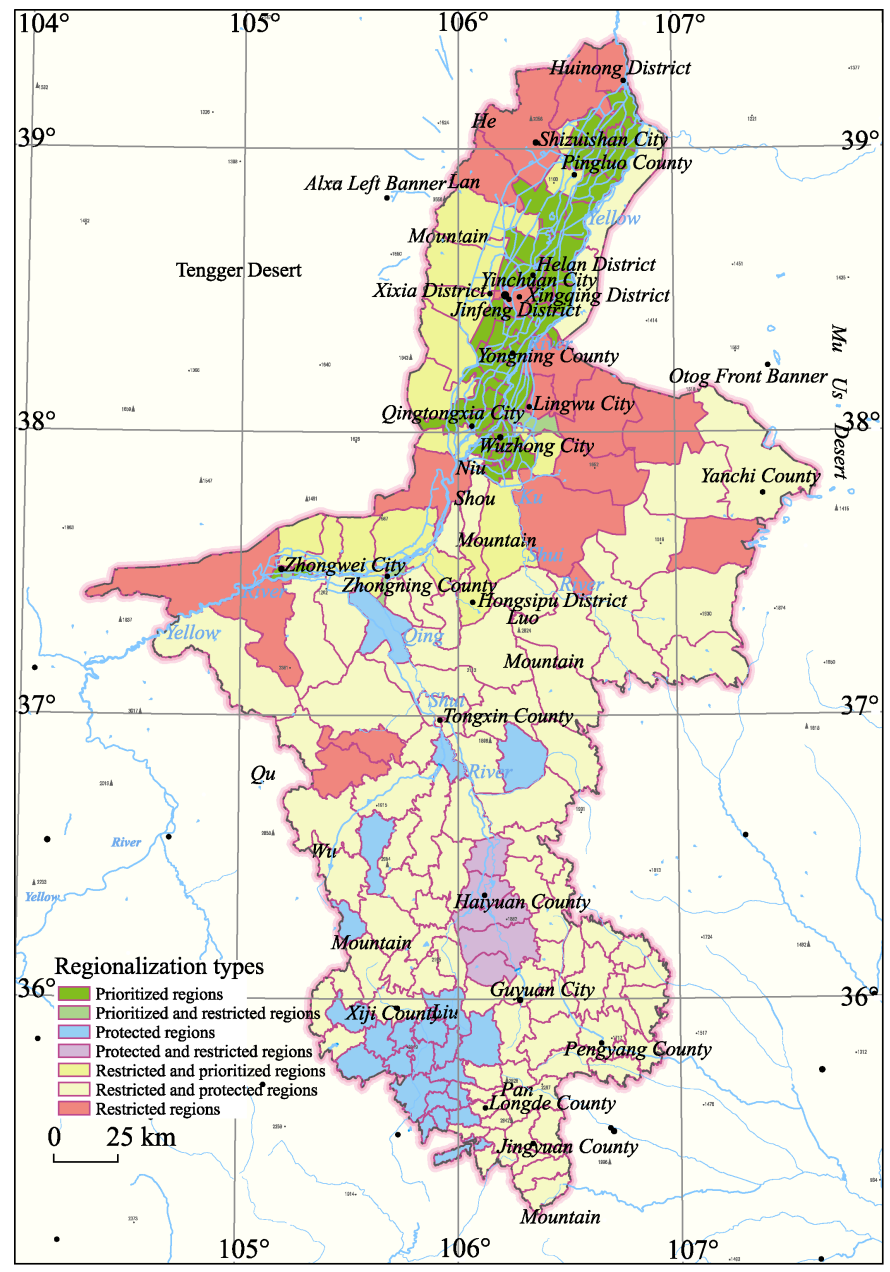

Figure 3 The spatial distribution of regionalization types for strategic transformation of Ningxia Agricultural Comprehensive Development

\subsection{Regionalization subtypes}

We further divided the 24 subtypes based on the seven types of regionalization (Figure 4 and Table 2). The prioritized regions, as well as the prioritized and restricted regions, are mainly located in the irrigated area of north Ningxia. (I) The prioritized regions include: (I1) the prioritized regions with paddy-dryland rotations in south Yinchuan, (I2) the prioritized regions with dryland in north Yinchuan and farmland with pumping irrigation in Taole, and 


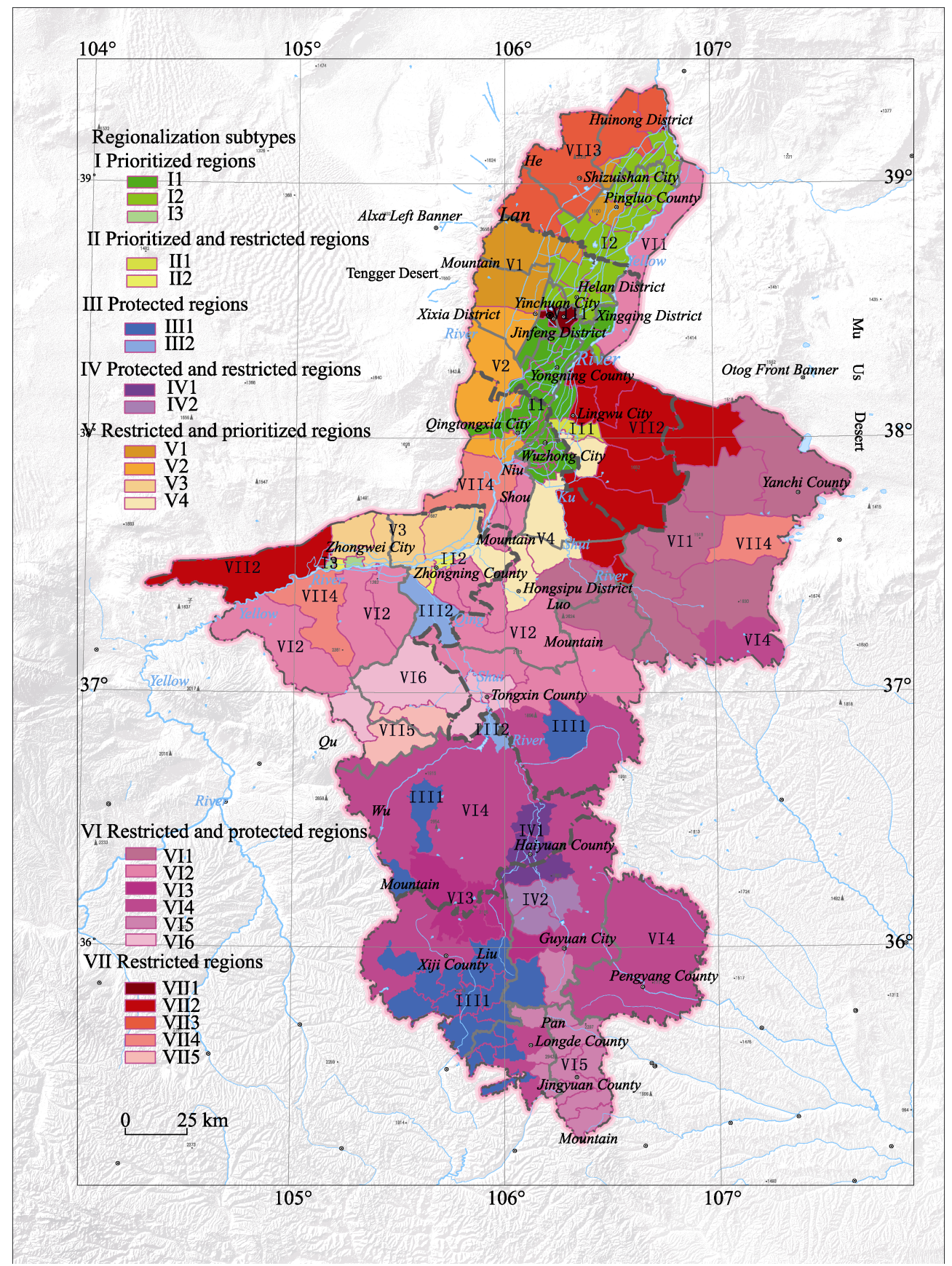

Figure 4 The spatial distribution of the regionalization subtypes of the strategy transformation for Ningxia Agricultural Comprehensive Development

(I3) the prioritized regions irrigated with water-saving reform in the Weining Plain. (II) The prioritized and restricted regions include: (II1) the prioritized regions with paddy-dryland rotations in south Yinchuan, and the restricted regions with sand prevention and control, and (II2) the prioritized and restricted regions with irrigated water-saving reform in the Weining Plain. 
The protected regions, as well as the protected and restricted regions, are mainly located in the loess hilly area of southern Ningxia, including the ecological zone of water-saving Table 2 The scheme for strategic transformation of regionalization for Ningxia Agricultural Comprehensive Development

\begin{tabular}{|c|c|}
\hline Types & Subtypes \\
\hline \multirow{3}{*}{$\begin{array}{l}\text { I The prioritized } \\
\text { regions }\end{array}$} & I1 The prioritized regions with paddy-dryland rotations in south Yinchuan \\
\hline & $\begin{array}{l}\text { I } 2 \text { The prioritized regions with dryland in north Yinchuan and farmland with pumping } \\
\text { irrigation in Taole }\end{array}$ \\
\hline & I3 The prioritized regions irrigated with water-saving reform in the Weining Plain \\
\hline \multirow{2}{*}{$\begin{array}{l}\text { II The prioritized and } \\
\text { restricted regions }\end{array}$} & $\begin{array}{l}\text { II1 The prioritized regions with paddy-dryland rotations in south Yinchuan, and the } \\
\text { restricted regions with sand prevention and control }\end{array}$ \\
\hline & $\begin{array}{l}\text { II } 2 \text { The prioritized and restricted regions irrigated with water-saving reform in the Weining } \\
\text { Plain }\end{array}$ \\
\hline \multirow{2}{*}{$\begin{array}{l}\text { III The protected } \\
\text { regions }\end{array}$} & III1 The protected regions with soil erosion and water-saving irrigation in the valley \\
\hline & III2 The protected regions with water-saving irrigation pumped from the Yellow River \\
\hline \multirow{2}{*}{$\begin{array}{l}\text { IV The protected and } \\
\text { restricted regions }\end{array}$} & $\begin{array}{l}\text { IV1 The protected regions with water-saving irrigation pumped from the Yellow River and } \\
\text { the restricted regions with soil erosion }\end{array}$ \\
\hline & $\begin{array}{l}\text { IV2 The protected regions with grass-crop rotations, and the restricted regions with forest } \\
\text { and grass }\end{array}$ \\
\hline \multirow{4}{*}{$\begin{array}{l}\mathrm{V} \text { The restricted and } \\
\text { prioritized regions }\end{array}$} & $\begin{array}{l}\text { V1 The restricted regions with forest and grass on Helan Mountain, and the prioritized } \\
\text { regions with irrigated dryland in north Yinchuan }\end{array}$ \\
\hline & $\begin{array}{l}\text { V2 The restricted regions with forest and grass on Helan Mountain, and the prioritized } \\
\text { regions with paddy-dryland rotations in south Yinchuan }\end{array}$ \\
\hline & $\begin{array}{l}\text { V3 The restricted regions with desert and semi-desert, and the prioritized regions with } \\
\text { irrigation water-saving transformation }\end{array}$ \\
\hline & V4 The restricted and the prioritized regions of desert steppe \\
\hline \multirow{6}{*}{$\begin{array}{l}\text { VI The restricted and } \\
\text { protected regions }\end{array}$} & VI1 The restricted and protected regions with sand prevention and control \\
\hline & VI2 The restricted and protected regions with desert steppe \\
\hline & VI3 The restricted and protected regions with forest and grass \\
\hline & VI4 The restricted and protected regions with soil erosion \\
\hline & VI5 The restricted and protected regions with water conservation \\
\hline & VI6 The restricted and protected regions returning cropland to grassland \\
\hline \multirow{5}{*}{$\begin{array}{l}\text { VII The restricted } \\
\text { regions }\end{array}$} & VII1 The restricted regions with urban construction \\
\hline & VII2 The restricted regions with sand prevention and control \\
\hline & VII3 The restricted regions with forest and grass on Helan Mountain \\
\hline & VII4 The restricted regions with desert steppe \\
\hline & VII5 The restricted regions being returned from cropland to grassland \\
\hline
\end{tabular}

irrigation farmland using water pumped from the Yellow River, and the ecological function regions of soil erosion control, and forest and grass protection, as well as of water and soil loss. In addition, the protected regions are also distributed within the ecological region of water-saving irrigation farmland that receives pumping from the Yellow River, in the arid area of central Ningxia. (III) The protected regions include: (III1) the protected regions with soil erosion and water-saving irrigation in the valley, and (III2) the protected regions with water-saving irrigation pumped from the Yellow River. (IV) The protected and restricted regions include: (IV1) the protected regions with water-saving irrigation pumped from the 
Yellow River and the restricted regions with soil erosion, and (IV2) the protected regions with grass-crop rotations, and the restricted regions with forest and grass.

The restricted regions, restricted and prioritized regions, and restricted and protected regions are mainly located in the north of Helan Mountain, in most areas of the arid zone in central Ningxia, and in the loess hilly regions in southern Ningxia. (V) The restricted and prioritized regions include: (V1) the restricted regions with forest and grass on Helan Mountain, and the prioritized regions with irrigated dryland in north Yinchuan, (V2) the restricted regions with forest and grass on the Helan Mountain, and the prioritized regions with paddy-dryland rotations in south Yinchuan, (V3) the restricted regions with desert and semi-desert, and the prioritized regions with irrigation water-saving transformation, and (V4) the restricted and the prioritized regions of desert steppe. (VI) The restricted and protected regions include: (VI1) those with sand prevention and control, (VI2) those with desert steppe, (VI3) those with forest and grass, (VI4) those with soil erosion, (VI5) those with water conservation, and (VI6) those being returned from cropland to grassland. (VII) The restricted regions include: (VII1) those with urban buildings, (VII2) those with sand prevention and control, (VII3) those with forest and grass on Helan Mountain, (VII4) those with desert steppe, and (VII5) those being returned from cropland to grassland.

\section{Suggestions on different development regions for ACD in Ningxia}

The irrigated area in northern Ningxia is mainly distributed to the east of Helan Mountain, in the Yellow River irrigation district, Taole plateau, several ditches on the left-hand side of the Yellow River, and the inland region of Gantang. This is the prioritized and essential agricultural development region. There are 43, three, and nine townships belonging to the prioritized regions, prioritized and restricted regions, and restricted and prioritized regions, respectively, accounting for more than $87 \%$ of the townships. In addition, there are seven townships belonging to the restricted regions and one township belonging to restricted and protected regions. These regions should continue to implement the modern agricultural projects of "one county-one character", high-standard farmland, and so on. In order to create high-quality modern agricultural areas, regional governors should accelerate the application of information technology, and promote the construction of production bases for highquality agricultural products such as green and organic foods. The advantages of location, information, market, science, and technology should be given full play, and modern agricultural ideas such as organic agriculture, intensive agriculture, precision agriculture, and high-value agriculture should be practiced in these regions. The aims are (i) to realize a high-quality, high-yield, high-efficiency system delivering high-value grain and other agricultural products, and (ii) to build a modern agricultural system with industries including high-quality grain, wolfberry, grape, dairy, and fisheries.

The arid area in central Ningxia is on the south of the region in northern Ningxia irrigated by the Yellow River, on the north of the loess hilly and gully region, on the west of the $\mathrm{Mu}$ Us Desert, and on the southeast of the Tengger Desert. Eighty-one percent of townships are situated in restricted or protected regions, and the others are in the restricted and prioritized regions, or the prioritized regions. The most serious problems in this area include scarce water resources, fragile ecology, poor quality of farmland, and natural disasters. In this re- 
gion, we should continue to support the projects of "one county-one character", water-saving, and ecological control; however, projects promoting high-standard farmland should be reduced. High-quality animal husbandry products should be developed in this region. Further, the water resources should be used rationally and the project patterns should be planned according to the distribution of water resources. For ecological control, efforts should be made to improve the ecosystem service function of sand prevention and control, as well as that of grassland maintenance.

The loess hilly area in southern Ningxia is located in the loess hilly and gully area and in parts of the Liupan Mountain. All townships in this region are in protected regions or restricted regions, including 58 restricted and protected regions, 21 protected regions, and five protected and restricted regions. Population overload, vegetation degradation, and soil and water loss are the most serious problems in this region. The main restrictive factors to agricultural production are the serious shortage of water resources, weak infrastructure, poor ability to resist natural disasters and low and unstable grain yields. In the protected regions, we should focus on building eco-agricultural regions on the northwest Loess Plateau, including the introduction of ecological agriculture in southern mountainous areas and the development of grass, livestock, and potato industries.

\section{Conclusions}

The strategic transformation of regionalization for the ACD is a basic development plan; to encourage sustainable development and improve competitiveness. This research is the first attempt at strategic transformation of regionalization for the ACD following the scientific classification of prioritized regions, protected regions, and restricted regions as presented by the Ministry of Finance of the People's Republic of China.

We took Ningxia as an example to study the principles and methods of strategic transformation of regionalization for the ACD, and presented multi-dimensional indices that are dynamic and static, qualitative and quantitative, agricultural and ecological. The type classification varies from pure types of agricultural regionalization to transitional types that achieve the goals of both sustainable agriculture and ecological protection.

This research is the first strategic transformation of regionalization for the ACD at a township (town) scale in a province or an autonomous region. This regionalization is convenient for the governors of the national and provincial ACD offices, and it can be used in enquiries, analysis, plotting, management, evaluation, and decision-making.

The results could provide an important basis for spatial planning and the implementation of strategic transformation of regionalization for the ACD in the future. Meanwhile, it could also provide an important reference for the strategic transformation of regionalization in other provinces or regions.

Some aspects still need improvement. First, we have not considered environmental pollution indices, due to the limited amount of data and the unpolluted water and soil in Ningxia. However, indices of environmental pollution should be considered, especially in other polluted regions. Second, the process of implementing regionalization should be applied step-by-step according to local conditions, and should determine the direction and focus for sustainable agricultural development in different ecological regions. Regionalization can 
provide a scientific basis for adjusting the plan for the ACD and for promoting the sustainable development of agriculture.

\section{References}

Agricultural Regionalization Research Team of Geographical Society of China, 1965. The New Delelopment of Agricultural Regionalization in China, 1965. Acta Geographica Sinica, 31(4): 269-276. (in Chinese)

Chen Xiaohong, Wang Yujuan, Wan Luhe et al., 2012. Study on the eco-agriculture regionalization based on hierarchical cluster analysis in Northeast China. Economic Geography, 32(1): 137-140. (in Chinese)

Deng Jingzhong, 1960. The Research Methodology of Agricultural Regionalization in China. Beijing: Science Press. (in Chinese)

Deng Jingzhong, 1982. Some problems on the comprehensive agricultural regionalization of China. Geographical Research, 1(1): 9-18. (in Chinese)

Deng Jingzhong, 1963. The preliminary discussion of national agricultural regionalization. Acta Geographica Sinica, 29(4): 265-280. (in Chinese)

Deng Jingzhong, 1984. Property, tasks and further problems of agricultural regionalization. Chinese Journal of Agricultural Resources and Regional Planning, 1: 57-68. (in Chinese)

Fan J, Li P, 2009. The scientific foundation of major function oriented zoning in China. Journal of Geographical Sciences, 19(5): 515-531.

Fan Jie, 2015. Draft of major function oriented zoning of China. Acta Geographica Sinica, 70(2): 186-201. (in Chinese)

Feng Zhiming, Pan Mingqi, Zhang Jing, 2006. Study on zoning of China's integrated land consolidation. Journal of Natural Resources, 21(1): 45-54. (in Chinese)

Government of the Ningxia Hui Autonomous Region, 2013. Atlas of Economic and Social Development of Ningxia and the Surrounding Neighboring Provinces. Beijing: Surveying and Mapping Press \& Sino Maps Press. (in Chinese)

Gu Chaolin, Zhang Xiaoming, Liu Jinyuan et al., 2007. The development spatial regionalization of Yancheng City and relevant consideration. Acta Geographica Sinica, 62(8): 787-798. (in Chinese)

Hou Xueyu, 1988. Chinese Ecological Regionalization and the Development Strategy of Big Agriculture. Beijing: Science Press. (in Chinese)

Huang Bingwei, 1959. China comprehensive natural zoning draft. Chinese Science Bulletin, 18: 594-602. (in Chinese)

Ji Yongzan, Yan Huimei, Liu Jiyuan et al., 2015. Spatial distribution pattern of Chinese high-yield, middle-yield and low-yield cultivated based on the MODIS data. Acta Geographica Sinica, 70(5): 766-778. (in Chinese)

Li Bingyuan, Pan Baotian, Cheng Weiming et al., 2013. Research on geomorphological regionalization of China. Acta Geographica Sinica, 68(3): 291-306. (in Chinese)

Lin Chao, 1954. Outline of physical geography regionalization in China. Acta Geographica Sinica, 20(4): 395-418. (in Chinese)

Liu Y, Zhang Y, Guo L, 2010. Towards realistic assessment of cultivated land quality in an ecologically fragile environment: A satellite imagery-based approach. Applied Geography, 30(2): 271-281.

Liu Yanhua, Zheng Du, Ge Quansheng et al., 2005. Problems on the research of comprehensive regionalization in China. Geographical Research, 24(3): 321-329. (in Chinese)

Liu Yuying, Shi Daming, Hu Yixin et al., 2013. Risk analysis and regionalization of agrometeorological drought hazard in Jilin Province of Northeast China. Chinese Journal of Ecology, 32(6): 1518-1524. (in Chinese)

Lv Xiaofang, Wang Yanglin, Zhang Yili et al., 2007. Research on agricultural functions regionalization and sustainable development strategy of ecologically vulnerable environment in the west of China: A case of Yanchi county in Ningxia Hui Autonomous Region. Journal of Natural Resources, 22(2): 177-184. (in Chinese)

Miao Bailing, Hou Qiong, Liang Cunzhu, 2015. Agricultural climate regionalization of dryland farming for potato 
in Yinshan based on GIS. Chinese Journal of Applied Ecology, 26(1): 278-282. (in Chinese)

Ren Mei'e, Yang Renzhang, 1961. Problems on the research of natural regionalization in China. Acta Geographica Sinica, 27(1): 66-74. (in Chinese)

Tao Hongjun, Chen Tizhu, 2014. Literature review on agricultural regionalization theory and practice research. Chinese Journal of Agricultural Resources and Regional Planning, 35(2): 59-66. The Agricultural Regionalization Research Team of Geographical Society of China.

The Second Land Survey of Ningxia Hui Autonomous Region Atlas Compilation Committee, 2012. The Second Land Survey of Ningxia Hui Autonomous Region Atlas. Beijing: Surveying and Mapping Press \& Sino Maps Press.

Wang Chuansheng, Zhao Haiying, Sun Guiyan et al., 2010. Function zoning of development optimized area at a county level: A case study of Shangyu, Zhejiang. Geographical Research, 29(3): 481-490. (in Chinese)

Wang Lianxi, Meng Dan, Geng Xiuhua et al., 2013. GIS based drought risk assessment and zoning in Ningxia. Journal of Natural Disasters, 22(5): 213-220. (in Chinese)

Wu Shaohong, Liu Weidong, 2005. An integrated approach to classification of territorial system: A case study of Tibetan Plateau. Geographical Research, 24(2): 169-177, 321. (in Chinese)

Xie Gaodi, Zhang Changshun, Zhang Linbo et al., 2012. China's country-scale ecological regionalization. Journal of Natural Resources, 27(1): 154-162. (in Chinese)

$\mathrm{Xu}$ Jitian, Chen Baiming, Zhang Xueqin, 2001. Ecosystem productivity regionalization of China. Acta Geographica Sinica, 56(4): 401-408. (in Chinese)

Zhao Songqiao, 1983. A new scheme for comprehensive physical regionalization. Acta Geographica Sinica, 38(1): 1-10. (in Chinese)

Zhao Yan, Wang Zhiguo, Sun Baoping et al., 2013. A primary study on scheme of soil and water conservation regionalization in China. Acta Geographica Sinica, 68(3): 307-317. (in Chinese)

Zheng Du, Ou Yang, Zhou Chenghu, 2008. Understanding of and thinking over geographical regionalization methodology. Acta Geographica Sinica, 63(6): 563-573. (in Chinese)

Zheng Jingyun, Yin Yunhe, Li Bingyuan, 2010. A new scheme for climate regionalization in China. Acta Geographica Sinica, 65(1): 3-12. (in Chinese)

Zhou Chenghu, Cheng Weiming, Qian Jinkai et al., 2009. Research on the classification system of digital land geomorphology of 1:1000000 in China. Journal of Geo-information Science, 11(6): 707-724. (in Chinese)

Zhou Lisan, 1979. The significance of agricultural regionalization and its relationship with agricultural modernization. Soil Fertilizer, (6): 3-7. (in Chinese)

Zhou Lisan, 1981. Some problems on the agricultural regionalization. Scientia Geographica Sinica, 1(1): 11-21. (in Chinese)

Zhou Lisan, 1993. Theory and Practice of Agricultural Regionalization in China. Hefei: University of Science and Technology of China Press. (in Chinese)

Zhou Lisan, Sun Han, Shen Yuqing, 1981. Comprehensive Agricultural Regionalization of China. Beijing: Agricultural Press. (in Chinese)

Zhou Qiye, 1957. Fundamental problems on the division of agricultural regions of China. Acta Geographica Sinica, 23(2): 127-144. (in Chinese) 